\title{
СУПРОВІД РОЗВИТКУ ПІЗНАВАЛЬНИХ ІНТЕРЕСІВ МОЛОДШИХ ШКОЛЯРІВ: ДІАГНОСТИЧНИЙ АСПЕКТ
}

\author{
Пуш О. А. \\ кандидат педагогічних наук, \\ викладач кафедри педагогіки, психології та окремих методик \\ КЗВО «Луиький педагогічний коледж» Волинської обласної ради \\ пр. Волі, 36, Луиькк, Україна \\ orcid.org/0000-0002-5838-521X \\ djulaj777@gmail.com \\ Яцик Т. О. \\ викладач кафедри педагогіки, психології та окремих методик \\ КЗВО «Луцький педагогічний коледж» Волинської обласної ради \\ пр. Волі, 36, Луиьк, Україна \\ orcid.org/0000-0003-0664-7115 \\ tetyanayacik@gmail.com
}

\author{
Замелюк М. I. \\ кандидат педагогічних наук, \\ викладач кафедри теорії та методики дошкільної освіти \\ КЗВО «Луцьький педагогічний коледж» Волинської обласної ради \\ пр. Волі, 36, Луцьк, Україна \\ orcid.org/0000-0001-6352-7908 \\ 1369301@ukr.net
}

\author{
Ключові слова: учень \\ початкової иколи, \\ допитливість, процес \\ учіння, навчальна діяльність, \\ готовність дитини \\ до навчання.
}

У статті проаналізовано діагностичний супровід розвитку пізнавальних інтересів молодших школярів. Стаття обгрунтовує важливість успішної навчальної діяльності молодшого школяра, яка тісно пов'язана з віковими, індивідуальними та психологічними особливостями дітей цього віку. Серед сприятливих рис пізнавального інтересу школярів дослідники виділяють загальне позитивне ставлення дітей до навчальної діяльності, широту інтересів і допитливості. Виправдано, що пізнавальний інтерес $\epsilon$ домінуючим серед інших мотивів діяльності шестирічних учнів, що суттєво змінює силу діяльності, впливає на характер дитини, розвивається раніше від інших мотивів, взаємодіючи з ними. Акцент робиться на формування навчальних інтересів на основі найпростіших інтересів до полегшення механічних видів роботи, наочності, ігрових моментів. Особлива увага приділяється індивідуальному, особистісно зорієнтованому підходам та гуманістичній педагогіці, суть яких полягає в безумовному визнанні цінності унікальності особистості кожної дитини і права на реалізацію їі властивостей і якостей, у найповнішому розкритті ії здібностей і задоволенні різноманітних освітніх потреб тощо. Акцент робиться на тому, щоб допомогти кожному учню соціалізуватися й адаптуватися до нового освітнього середовища шляхом оптимального розвитку його потенційних можливостей, здібностей, нахилів та інтересів. Охарактеризовано цикли діагностичного супроводу: діагностичний супровід розвитку пізнавальних інтересів дошкільника-абітурієнта упродовж шести місяців до початку навчання в школі; діагностичний 
супровід розвитку пізнавальних інтересів школяра-початківця. Закінчення цього етапу пов'язується iз виявленням більшістю учнів якостей, характерних для молодшого шкільного віку. Зазначається, що у результаті проведеного експерименту було визначено критерії оцінки рівня розвитку пізнавальних інтересів у дітей молодшого шкільного віку. Обгрунтовані результати первинної діагностики за методикою «Оцінка рівня сформованості навчальної діяльності» учнів 3-го класу та шляхи розвитку пізнавальної діяльності молодших школярів на уроках математики.

\title{
SUPPORT OF DEVELOPMENT OF COGNITIVE INTERESTS OF YOUNG SCHOOLCHILDREN: DIAGNOSTIC ASPECT
}

\author{
Push O. A. \\ Candidate of Pedagogical Sciences, \\ Lecturer at the Department of Pedagogy, Psychology and Separate Methods \\ Lutsk Pedagogical College of the Volyn Regional Council \\ Volya ave., 36, Lutsk, Ukraine \\ orcid.org/0000-0002-5838-521X \\ djulaj777@gmail.com \\ Yatsyk T. O. \\ Lecturer at the Department of Pedagogy, Psychology and Separate Methods \\ Lutsk Pedagogical College of the Volyn Regional Council \\ Volya ave., 36, Lutsk, Ukraine \\ orcid.org/0000-0003-0664-7115 \\ tetyanayacik@gmail.com \\ Zamelyuk M. I. \\ Candidate of Pedagogical Sciences, \\ Lecturer at the Department of Theory and Methods of Preschool Education \\ Lutsk Pedagogical College of the Volyn Regional Council \\ Volya ave., 36, Lutsk, Ukraine \\ orcid.org/0000-0001-6352-7908 \\ 1369301@ukr.net
}

Key words: primary school student, curiosity, learning process, learning activities, readiness of the child to learn.
The article analyzes the diagnostic support for the development of cognitive interests of primary school children. The article substantiates the importance of successful learning activities of primary school students, which is closely related to the age, individual and psychological characteristics of children of this age. Among the favourable features of cognitive interest of schoolchildren, researchers highlight the general positive attitude of children to learning, the breadth of interests and curiosity. It is justified that cognitive interest is dominant among other motives of six-year-old students, which significantly changes the strength of activity, affects the character of the child, develops earlier than other motives, interacting with them. Emphasis is placed on the formation of educational interests on the basis of the simplest interests in the facilitation of mechanical work, clarity, game moments. Particular attention is paid to individual, personality-oriented approaches and humanistic pedagogy, the essence of which is to unconditionally recognize the value of the uniqueness of each child's personality and the right to realize its properties and qualities, the fullest disclosure of its abilities and various educational needs. The emphasis is on helping each student to socialize and adapt to the 
new educational environment by optimally developing his or her potential, abilities, inclinations, and interests. The cycles of diagnostic support are characterized: diagnostic support of the development of cognitive interests of the preschooler-entrant during six months before the beginning of schooling; diagnostic support of development of cognitive interests of the beginner schoolboy. The end of this stage is associated with the discovery by most students of qualities characteristic of primary school age. It is noted that as a result of the experiment the criteria for assessing the level of development of cognitive interests in children of primary school age were determined. The results of primary diagnostics according to the method "Assessment of the level of formation of educational activity" of 3rd grade students and the ways of development of cognitive activity of junior schoolchildren in mathematics lessons are substantiated.

Постановка проблеми. Успішна навчальна діяльність молодшого школяра тісно пов'язана 3 віковими, індивідуальними та психологічними особливостями дітей цього віку.

Аналізуючи особливості розвитку пізнавального інтересу молодших школярів, учені (Н. Бібік, О. Киричук, Г. Костюк, Л. Проколієнко, О. Савченко, Н. Скрипниченко, О. Скрипниченко, Р. Пріма та ін.) відзначають, що вони можуть мати як позитивні, так і негативні аспекти. Серед сприятливих рис пізнавального інтересу школярів дослідники виділяють загальне позитивне ставлення дітей до навчальної діяльності, широту інтересів і допитливості.

Мета статті - проаналізувати діагностичний супровід розвитку пізнавальних інтересів молодших школярів.

Виклад основного матеріалу дослідження. У шестирічному віці важливою є роль емоційного аспекту інтересу: яскраво виявляються симпатії й антипатії дітей, любов до вчителя, ровесників, об'єктів діяльності, характерна радість переживання від виконання поставлених завдань. Водночас інтереси мають романтичний характер, учнів цікавить усе героїчне, пригодницьке, фантастичне. Відвертість, довірливість першокласників, їхня віра в авторитет учителя, готовність виконувати будь-які завдання $\epsilon$ як умовами, так і наслідками формування у цьому віці широких соціальних і навчально-пізнавальних мотивів, обов'язку, відповідальності.

Зокрема, Т. Пушкарьова пізнавальний інтерес розглядає як найбільш домінуючий серед інших мотивів діяльності шестирічних учнів, що суттєво змінює силу діяльності, впливає на характер дитини, розвивається раніше від інших мотивів, взаємодіючи $з$ ними [4, с. 84].

Крім того, дослідниця зазначає, що пізнавальні інтереси першокласників мають також і негативні характеристики, що перешкоджають процесу учіння (рис. 1).

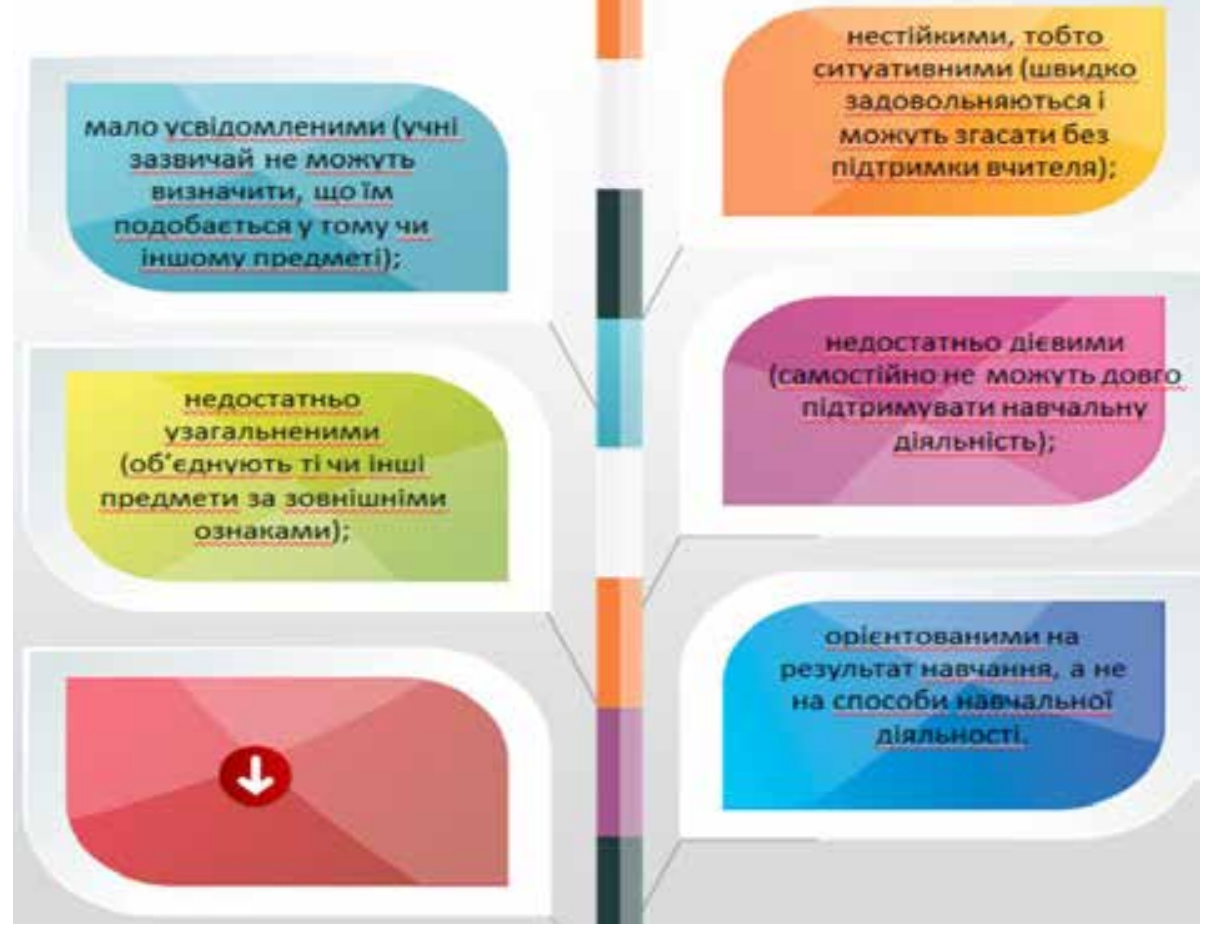

Рис. 1. Інтереси дітей $[4$, с. 85] 
Лише наприкінці молодшого шкільного віку 3'являється інтерес до причинно-наслідкових зв'язків, закономірностей, а потім і до способів здобуття знань. Більшість учених пропонують сформувати мотиви, що спонукають до навчальної діяльності й надають їй визначеної сутності, зокрема, за допомогою формування навчальних інтересів на основі найпростіших інтересів до полегшення механічних видів роботи, наочності, ігрових моментів (Я. Кодлюк, С. Коробко, О. Проскура, О. Савченко, 3. Шабаліна та інші).

Аналіз теоретичних джерел показав, що діагностичний супровід розвитку пізнавальних інтересів молодших школярів грунтується на індивідуальному, особистісно зорієнтованому підходах та гуманістичній педагогіці, суть яких полягає в безумовному визнанні цінності унікальності особистості кожної дитини і права на реалізацію їі властивостей і якостей, у найповнішому розкритті ії здібностей і задоволенні різноманітних освітніх потреб тощо.

Відповідно до наявних рекомендацій (В. Бондар, С. Мартиненко, О. Митник, О. Проскура та ін.) методики, що застосовуються в роботі 3 першокласниками, мають відповідати не тільки меті дослідження, віковим особливостям учнів, а й бути короткочасними, оскільки довготривалі методики вимагають великих вольових зусиль від дітей, що можуть спричинити необ'єктивність отриманих даних. Вони мають відповідати встановленим психодіагностичним професійним стандартам, тобто бути надійними і валідними. Під надійністю ми розуміємо узгодженість результатів багаторазового використання методики щодо однієї групи тих, кого досліджують. Валідність - це другий основний критерій оцінювання якості методики, що вказує, наскільки повно вона вимірює те, що досліджується. Надійність і валідність забезпечують достовірність результатів психолого-педагогічного вимірювання, самих кваліметричних процедур.

Відповідно, мета діагностичного супроводу розвитку пізнавальних інтересів молодших школярів у процесі їх підготовки до навчання та навчання в початковій школі полягає в тому, щоб допомогти кожному учню соціалізуватися й адаптуватися до нового освітнього середовища шляхом оптимального розвитку його потенційних можливостей, здібностей, нахилів та інтересів. Діти мають різні індивідуально-психологічні особливості, інтереси та схильності, різняться типом поведінки і стилем діяльності, рівнем розвитку загалом, але кожна дитина має право на прояв і повноцінний розвиток свого потенціалу.

Діагностичний супровід розвитку пізнавальних інтересів молодших школярів має допомогти педагогу знайти необхідні засоби для успішного навчання й виховання дітей, даючи їм можливість проявляти свої інтереси, потреби, самостійність та творчість.

Діагностичний супровід як метод роботи вчителя початкових класів $\epsilon$ системно організованою діяльністю, спрямованою на допомогу оптимальному розвитку кожного учня - його пізнавальній діяльності, прагненню до знань і самостійної творчої роботи.

На думку С. Коробко, О. Коробко, засобами реалізації цієї системно організованої діяльності є: вивчення психічного розвитку учня й умов його навчання й виховання; діагностична й розвивальна робота вчителя 3 дитиною в індивідуальних або групових формах [2, c. 7-8].

Діалектика процесу супроводу полягає в тому, щоб виявити розвиток пізнавальних інтересів молодшого школяра і допомогти дитині максимально використати надані педагогічним середовищем можливості для освіти та розвитку й одночасно адаптувати (пристосувати) іiі індивідуальні особливості до умов шкільної життєдіяльності.

Конкретні завдання діагностичного супроводу розвитку пізнавальних інтересів визначаються 3 урахуванням складу життєдіяльності дитини на різних етапах освіти в рамках початкової школи i перед нею (рис. 2).
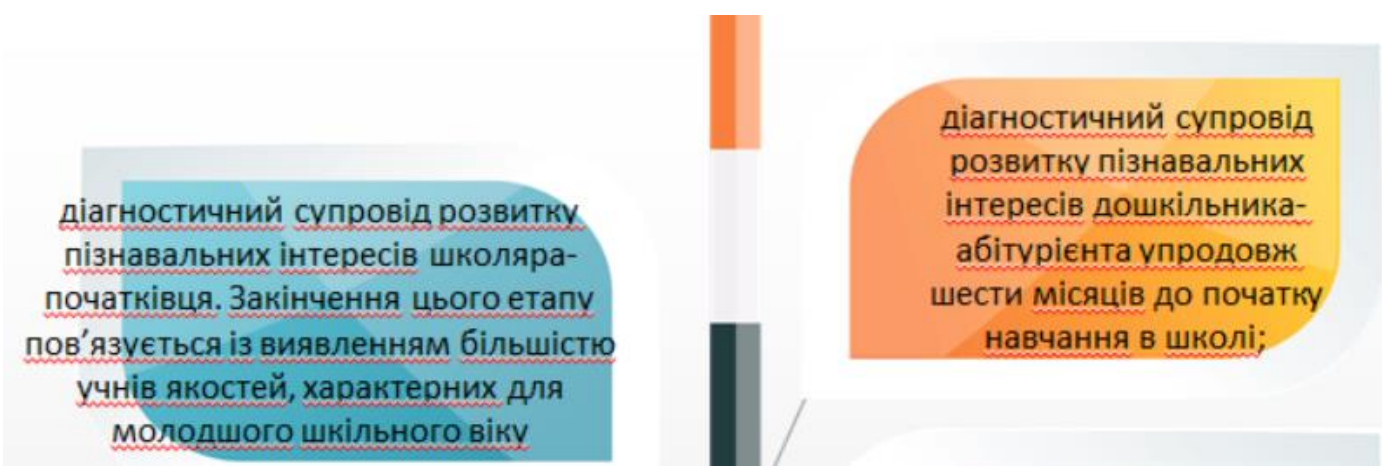

Рис. 2. Цикли діагностичного супроводу розвитку пізнавальних інтересів школярів 
Цикл 1. Діагностичний супровід починається із першої зустрічі з майбутнім учнем. За бажанням та згодою батьків під час іiї проведення може бути здійснене діагностування психологічної готовності дитини до школи. 3 цією метою до бесіди включається система портативних тестових завдань, які спрямовані на визначення розвитку пізнавальних інтересів дитини (наприклад, методика «Бесіда» (М. Марусинець), методика 3 визначення домінування пізнавального або ігрового мотиву в афективно-потребовій сфері дитини (Н. Гуткіна)). Отримана 3 їх допомогою інформація дає змогу вчителеві зробити консультацію більш конкретною. Дитина має отримувати насолоду від знайомства з уже недалеким майбутнім, переконатися в тому, що в школі багато цікавого та невідомого, вона зможе успішно навчатися, звісно, якщо постарається. Більшість дітей наступного разу приходять до школи уже в ролі першокласника.

Як стверджують С. Коробко, О. Коробко, головне завдання діагностичного супроводу полягає у стимуляції прояву і розвитку передумов для успішного навчання дитини в школі. На неї працюють усі можливі у цей період засоби: виявлення рівня готовності дитини до школи, рекомендації батькам, загальний стиль спілкування 3 дитиною тощо [2, с. 8].

Батьків слід переконати, що готовність до школи розглядається насамперед як загальна готовність. Вона включає фізичну готовність (фізичну працездатність, розвиненість рухових навичок і якостей, особливо тонких координацій, що лежать в основі оволодіння графікою письма), особисту готовність (довільність поведінки, сформованість спілкування, самооцінки, мотивації навчання), інтелектуальну готовність (розвиток образного мислення, уяви, творчості, а також основ словесно-логічного мислення).
Навички читання, лічби і письма не входять до обов'язкових (рис. 3).

Але якщо у дитини відсутній інтерес до навчання у школі, а особливо пізнавальний інтерес до нових знань, уявлень, навколишнього, то не лише навчальна, але й ігрова, комунікативна, трудова діяльності будуть не досить розвиватися.

Цикл 2. Завдання діагностичного супроводу розвитку пізнавальних інтересів школяра-початківця й засоби їх вирішення - діагностична та розвивальна діяльність вчителя - підлягають вимогам адаптації дитини до систематичного навчання та шкільного типу взаємин.

На основі узагальнення інформації про рівні розвитку пізнавального інтересу (рис. 4) можна виділити такі прояви інтересу: споглядальний, споглядально-дійовий, пізнавальний, пізнавально-творчий, теоретичний, конструктивно-творчий.

Апробація трансформованої нами програми діагностичного супроводу щодо розвитку пізнавальних інтересів молодших школярів здійснювалася на базі ОЗ3СО «Торчинський ліцей Торчинської селищної ради». В експерименті взяли участь 28 учнів третіх класів (14 - експериментальна група, 14 - контрольна).

Була відібрана методика, призначена для визначення рівня розвитку пізнавальної діяльності в учнів 3-х класів, - методика «Оцінка рівня сформованості навчально-пізнавальної діяльності» (Г. Репкина, Є. Заїка). Мета такої методики - діагностика рівня сформованості компонентів навчальної діяльності. Діагностика виконувалася за інструкцією.

Результати діагностування за методикою «Оцінка рівня сформованості навчальної діяльності». У формуванні кожного компонента виділяють шість рівнів: низький, нижчий за середній, середній, вищий за середній, підвищений, високий.

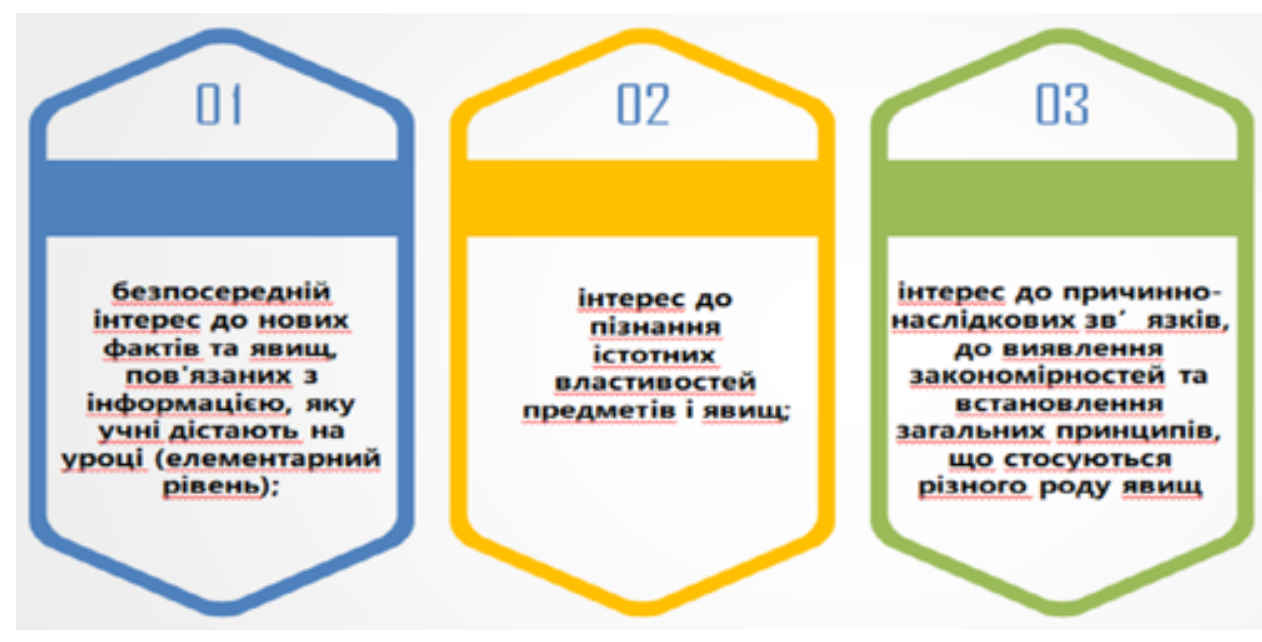

Рис. 3. Рівні розвитку пізнавального інтересу школярів 


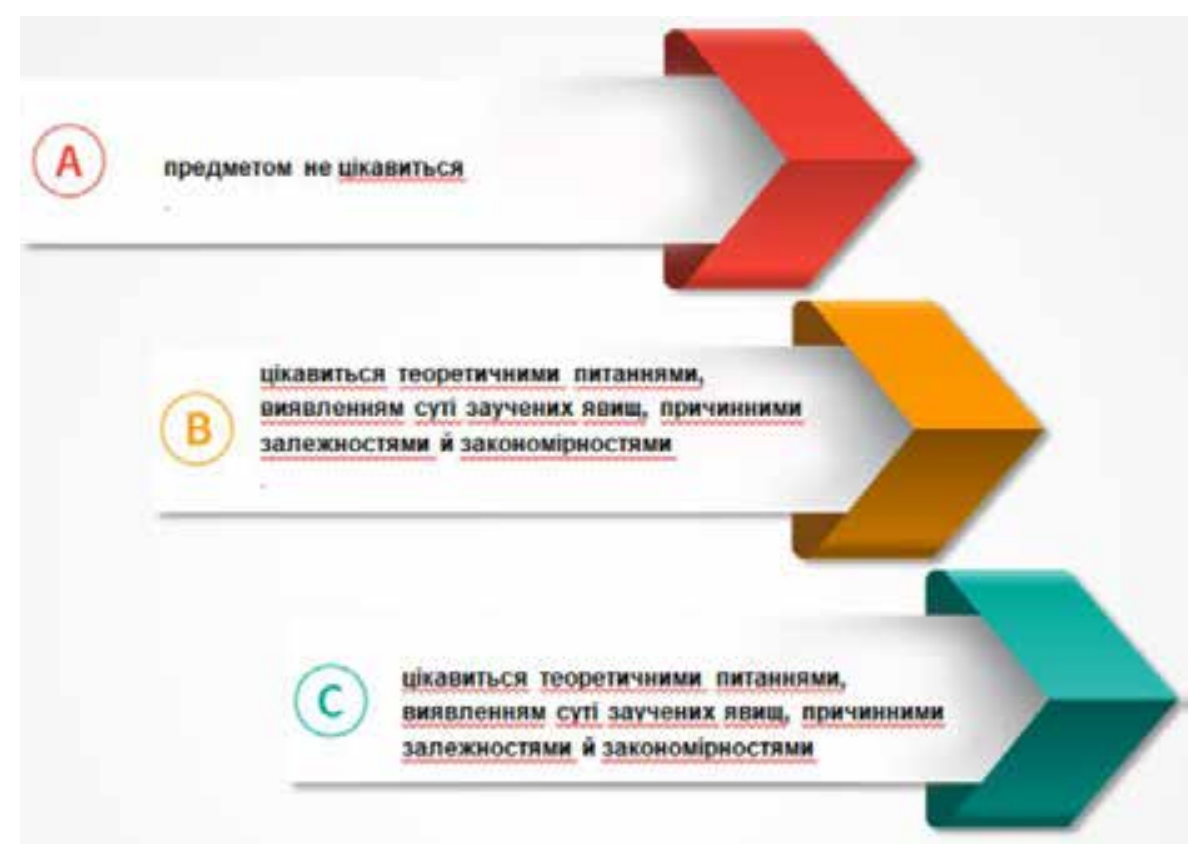

Рис. 4. Показники рівня розвитку пізнавального інтересу школярів (Голуб Н.)

Для того щоб визначити загальний рівень пізнавальної діяльності, рівні сформованості компонентів були об'єднані: низький і нижчий за середній, середній і вищий за середній, підвищений і високий. У кінцевому підсумку ми виділили три рівні розвитку пізнавальної діяльності: низький, середній і високий.

Низький рівень - позитивні реакції виникають на новий матеріал, не проявляється стійкої активності. Погано розрізняють навчальні завдання, виділяють лише проміжні цілі, цілеспрямованих дій не здійснюють. Під час виконання навчальних дій виконують окремі операції, дають звіт своїм діям, але не можуть їх втілити. Навчальні дії не контролюються систематично, можуть виправити помилки, але не обгрунтовують своїх дій. Потреби в оцінці не відчувають, самостійно себе не оцінюють, чекають зовнішньої оцінки.

Середній рівень - позитивні реакції на новий матеріал, активно включаються в роботу, після вирішення навчального завдання інтерес пропадає. Пізнавальна задача зберігається в ході навчальних дій. До вирішення навчального завдання застосовують засвоєний спосіб рішення, не можуть внести зміни в спосіб рішення самостійно, тільки за допомогою вчителя. Виявляють помилки самостійно і виправляють, обгрунтовують це. Контролюють процес вирішення. Самостійно оцінюють свої дії і можуть обгрунтувати правильність і помилковість результату. Перед тим як приступити до вирішення завдання, оцінюють свої можливості.

Високий рівень - виникає стійкий інтерес, проявляється творче зацікавлене ставлення до пред- мета. Чітко усвідомлюють навчальне завдання, самостійно формулюють мету. Самостійно будують спосіб вирішення або модифікують відомий спосіб. Під час вирішення нового завдання застосовують до нього стару схему, завдання виконують безпомилково, у разі необхідності вносять корективи до початку виконання. До вирішення завдання можуть оцінити свої можливості i обгрунтувати можливість або неможливість його вирішення.

Результати первинної діагностики за методикою «Оцінка рівня сформованості навчальної діяльності» учнів 3-го класу мають такі рівні сформованості компонентів навчально-пізнавальної діяльності:

1) Мотиви. Середній рівень мають 7 осіб $28 \%$, у яких виникає позитивна реакція на новий матеріал, вони активно включаються в роботу, але після іiі виконання інтерес пропадає. Рівень нижчий за середній мають 13 осіб - 52\%, позитивна реакція виникає тільки на новий матеріал, активність не тривала і не стійка. Низький рівень 5 осіб (20\%) - інтересу практично не виникає.

2) Цілепокладання. Середній рівень - 3 людини $(12 \%)$ - пізнавальна мета не стійка, включаються у вирішення пізнавального завдання, під час виконання завдання орієнтуються тільки на практичну частину і не досягають пізнавальної мети. Нижчий за середній - 10 осіб $(40 \%)$ - не здійснюють цілеспрямовано дії, виконують тільки практичні завдання. Низький рівень -12 осіб (48\%) - мета відсутня, включаються в роботу, але не розуміють для чого. 


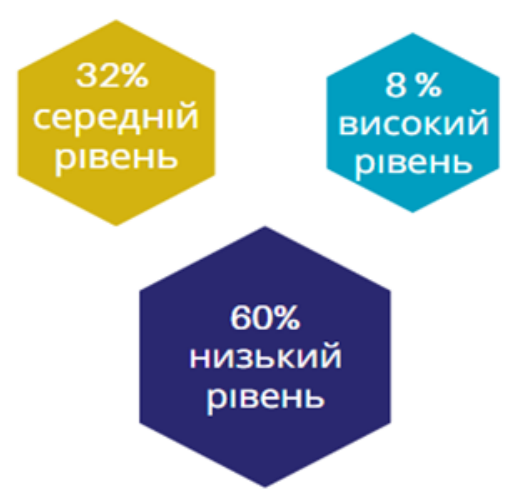

\section{Рис. 5. Рівні розвитку пізнавальних інтересів школярів}

3) Навчальні дії. Середній рівень - 3 людини (12\%) - можуть застосувати відпрацьовані багаторазово навчальні дії на новому завданні, але не здатні вносити зміни. Нижчий за середній 10 осіб (40\%) - виконують навчальні дії і співробітництво з учителем. Без допомоги вчителя не можуть організувати свої навчальні дії. Низький рівень - 12 осіб (48\%) - не виконують навчальні дії в цілому, лише окремі операції. Звіту своїм діям дати не можуть.

4) Контроль. Рівень вищий за середній 3 людини (12\%). Середній рівень - 6 осіб (24\%) виправляють і обгрунтовують помилки відповідно до відпрацьованої схеми. Рівень нижчий за середній - 15 осіб $(60 \%)$ - безсистемно і несвідомо знаходять помилку, можуть ії виправити, але не обгрунтовують. Низький рівень - 1 людина (4\%) не контролюють свої дії, як і не бачать помилки, не можуть виправити помилки навіть після того, як на них було вказано.
5) Оцінка. Рівень вищий за середній - 2 людини (8\%). Середній рівень - 6 осіб (24\%) - оцінюють себе після вирішення завдання, перед вирішенням неможливо. Здатні оцінити дії інших. Рівень нижчий за середній -14 осіб $(56 \%)$ - не вміють оцінювати себе, чекають зовнішньої оцінки. Низький рівень 3 людини (12\%) - не намагаються оцінити свої дії.

Висновки. Отже, за діаграмами ми бачимо, що в учнів 3-го класу переважає низький рівень розвитку пізнавальної діяльності (60\%). В учнів, які перебувають на цьому рівні, виникає інтерес на новий матеріал, пізнавальна мета не стійка, вирішують навчальне завдання засвоєними раніше способами, але не здатні вносити зміни в спосіб вирішення. Після виконання дій можуть знайти помилки, виправити їх без обгрунтування. Себе оцінити вони не можуть, чекають зовнішньої оцінки з боку.

8 учнів 3-го класу мають середній рівень пізнавальної діяльності (32\%). Ті, що навчаються 3 інтересом, реагують на новий матеріал, після вирішення навчального завдання інтерес пропадає. У вирішенні навчального завдання застосовують засвоєний спосіб, не вносять зміни, можуть проконтролювати процес вирішення за запропонованою схемою, самостійно оцінюють свої дії.

2 людини (8\%) перебувають на високому рівні розвитку пізнавальної діяльності. Ті, що навчаються, виявляють стійкий інтерес, самостійно ставлять перед собою навчальне завдання, вносять корективи в план вирішення навчального завдання, оцінюють свої можливості перед вирішенням і обгрунтовують свої дії.

Підсумки, які були отримані в результаті діагностики рівня розвитку пізнавальної діяльності, сприяли підбору методів і прийомів, які будуть спрямовані на розвиток пізнавальної діяльності молодших школярів на уроках математики.

\section{ЛІТЕРАТУРА}

1. Голуб Н.М. Умови формування стійких пізнавальних інтересів у дітей 6-річного віку. Матеріали IV Міжнародної наук.-практ. конф. «Сучасні проблеми гуманізачії та гармонізащії управління». Харків : Українська Асоціація «Жінки в науці та освіті», ХНУ ім. В.Н. Каразіна 2003. С. 186-187.

2. Коробко С.Л. Робота психолога з молодшими школярами : методичний посібник. Київ : Літера ЛТД, 2006. $416 \mathrm{c}$.

3. Матвійчик В. Психолого-педагогічні аспекти роботи з обдарованими дітьми. Психологічна газета. 2007. № 10.

4. Пушкарьова Т.Е. Дидактичні умови організації особистісно орієнтованої навчально-пізнавальної діяльності шестирічних учнів : дис. ... канд. пед. наук : 13.00.09. Київ, 2010. 259 с.

\section{REFERENCES}

1. Holub, N.M. (2003). Umovy formuvannia stiikykh piznavalnykh interesiv u ditei 6-richnoho viku. Materialy IV Mizhnarodnoi nauk.-prakt. konf. "Suchasni problemy humanizatsii ta harmonizatsii upravlinnia". Kharkiv : Ukrainska Asotsiatsiia "Zhinky v nautsi ta osviti”, KhNU im. V.N. Karazina. P. 186-187.

2. Korobko, S.L. (2006). Robota psykholoha z molodshymy shkoliaramy: metodychnyi posibnyk. Kyiv : Litera LTD. $416 \mathrm{~s}$.

3. Matviichyk, V. (2007). Psykholoho-pedahohichni aspekty roboty z obdarovanymy ditmy. Psykholohichna hazeta. No. 10.

4. Pushkarova, T.E. (2010). Dydaktychni umovy orhanizatsii osobystisno oriientovanoi navchalnopiznavalnoi diialnosti shestyrichnykh uchniv: dys. ... kand. ped. nauk : 13.00.09. Kyiv. $259 \mathrm{~s}$. 